\title{
A NEW CETRIMIDE MEDIUM FOR THE DETECTION OF PSEUDOMONAS AERUGINOSA
}

\author{
D. A. A. Mossel* aNd LouRdes Indacochea $\dagger$ \\ *Central Institute for Nutrition and Food Research TNO, Zeist, The Netherlands, \\ and $†$ San Marcos University, Lima, Peru
}

\begin{abstract}
Estimates of the numbers of Pseudomonas aeruginosa in food, water supplies and medicaments may be made either by direct enumeration methods (Selenka, 1960; Drake, 1966; Kielwein, 1969), or by presence-or-absence tests (Favero, Drake and Randall, 1964; Black et al., 1970). In the former, material is seeded on to a solid diagnostic medium and the relevant colonies are counted; in the latter, portions are first enriched in a liquid selective medium and streaks are subsequently made on to a similar solid medium. Cetrimide agar (Lowbury and Collins, 1955; Brown and Lowbury, 1965) is a useful medium for this purpose, but it is not completely selective for Ps. aeruginosa (Goto and Enomoto, 1970); and colonies of this organism on it cannot always be identified with certainty unless confirmatory tests are made (Azuma and Witter, 1970).
\end{abstract}

\section{Preliminary EXPERIMENTS}

An attempt was made to increase the diagnostic value of the cetrimide medium by making use of three fairly constant metabolic attributes of Ps. aeruginosa: (1) rapid growth at $41^{\circ}-42^{\circ} \mathrm{C}$ (Seleen and Stark, 1943; Haynes, 1951; Stanier, Palleroni and Doudoroff, 1966); (2) no formation of acid from polyols (Mossel and Indacochea, unpublished) and (3) rapid deamination of acetamide (Bühlmann, Vischer and Bruhin, 1961; Kelly and Clark, 1962; Hedberg, 1969).

Hedberg's peptone-free acetamide agar was first tried as the basal medium; but, as shown by Hedberg herself, it readily supported the growth of some other Gram-negative bacteria. Moreover, we found that approximately 20 per cent. of some 200 strains of Ps. aeruginosa freshly isolated from clinical material did not deaminate acetamide on Hedberg's medium at $42^{\circ} \mathrm{C}$.

Next, acetamide was added to Brown and Lowbury's modified cetrimide agar. Brown and Lowbury included glycerol in their medium to promote pigment formation. This was useful for our purpose also, because the enterobacteria that were able to grow on this medium and to attack glycerol produced sufficient acid to mask any alkalinity resulting from the deamination of acetamide. However, some of them did not attack glycerol, and such strains might deaminate acetamide and hence be recorded as Ps. aeruginosa. This was remedied by replacing half the glycerol by D-mannitol, from which such strains produce acid; virtually all of the Enterobacteriaceae produce acid either from glycerol or mannitol. Phenol red was included in the medium as indicator to reveal whether or not the net effect of polyol dissimilation and acetamide deamination is alkalinisation of the medium as in the case of Ps. aeruginosa. A red zone around the area of growth was therefore taken to be presumptive evidence for the presence of this organism. The medium thus composed was called GMAC (glycerol-mannitol-acetamide-cetrimide) agar.

\section{COMFOSITION OF THE MEDIUM}

To prepare the medium, $0.2 \mathrm{~g}$ peptone, $10 \mathrm{~g} \mathrm{~K}_{2} \mathrm{SO}_{4}, 1 \cdot 4 \mathrm{~g} \mathrm{MgCl}_{2} .6 \mathrm{H}_{2} \mathrm{O}, 0.3 \mathrm{~g}$ cetrimide (AR), $5 \mathrm{ml}$ glycerol (AR), $5 \mathrm{~g} \mathrm{D}$-mannitol (AR) and $15 \mathrm{~g}$ agar were added to $900 \mathrm{ml}$ distilled water; the $p \mathrm{H}$ was adjusted to 7.0 and the mixture sterilised for $20 \mathrm{~min}$. at $118^{\circ}-121^{\circ} \mathrm{C}$;

Received 9 June 1970; accepted 28 Oct. 1970.

J. MED. MICROBIOL.-VOL. 4 (1971) 
this basal medium was brought to a temperature of $50^{\circ} \mathrm{C}$, and $100 \mathrm{ml}$ of a solution containing $10 \mathrm{~g}$ acetamide (AR) and $12 \mathrm{mg}$ phenol red, adjusted to $p \mathrm{H} 7.0$ and sterilised by filtration, was added with aseptic precautions. The medium was dispensed, either in thin layers in Kolle flasks (rather than in petri dishes) to allow incubation in a waterbath at $42 \pm 0 \cdot 1^{\circ} \mathrm{C}$ after surface plating, or as slopes in test-tubes for making subcultures from liquid enrichment media.

The fully prepared medium had a faint yellow-orange colour.

\section{EVALUATION OF THE MEDIUM}

For qualitative evaluation of the medium, a total of 450 freshly isolated cultures of $P$ s. aeruginosa from clinical material was examined. In addition some 100 other bacteria were tested, including three to five cultures each of Acinetobacter, Aeromonas, Alkaligenes, Arizona, Bacillus, Citrobacter, Corynebacterium, Enterobacter, Escherichia, Flavobacterium, Herellea, Klebsiella, Micrococcus, Proteus, Salmonella, Shigella, group-D streptococci, Staphylococcus, Vibrio and Yersinia. Tubes of GMAC-agar were streak-inoculated and then incubated in a waterbath at $42 \pm 0 \cdot 1^{\circ} \mathrm{C}$. The colour of the slants was observed after 24 hours' and approximately 40 hours' incubation. With six exceptions, all strains of Ps. aeruginosa grew prolifically and changed the colour of the slants to cherry red. Among the other bacteria tested, most did not grow at all on the medium. Some Gram-negative rods grew but, except for one strain of Alkaligenes, did not change the colour of the medium to red.

In addition, the performance of GMAC-agar was tested for the enumeration of Ps. aeruginosa in contaminated materials. Samples of sewage and lake water were spread directly on GMAC-agar contained in Kolle flasks, and incubated at $42 \pm 0.1^{\circ} \mathrm{C}$; colonies surrounded by red zones were picked. To recognise individual colonies of $P$ s. aeruginosa when the medium was thus used for direct inoculation it was necessary to restrict the size

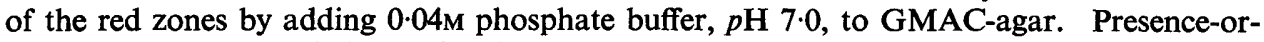
absence tests were carried out with the same samples by enriching suitable portions of water at $42 \pm 0 \cdot 1^{\circ} \mathrm{C}$ for $20 \mathrm{hr}$ in a liquid medium (PCTK) that contained $15 \mathrm{~g}$ sugar-free peptone, $1 \mathrm{mg}$ crystal violet, $15 \mathrm{mg}$ kanamycin and $50 \mathrm{mg}$ tylosin per 1 water. Such enrichment cultures were streaked on to slants of GMAC-agar, incubated at $42 \pm 0 \cdot 1^{\circ} \mathrm{C}$. The result was considered positive when the colour of the slants changed to cherry red. In parallel with the above two tests, similar portions of the samples were examined by the standard American method (Favero et al.; Black et al.). The direct plating method yielded almost as many positive results as the standard method, and the enrichment technique yielded slightly more.

The confirmation rate of suspect colonies obtained on GMAC-agar, when it was used as a plating medium after enrichment of samples in PCTK, was over 90 per cent. Occasional strains of Alkaligenes and a rare strain of Ps. stutzeri could be rejected by testing for oxidase, the mode of attack on glucose (Mossel and Martin, 1961), arginine dihydrolase and amylase activity (Stanier et al.; Pickett and Pedersen, 1970).

\section{SUMMARY}

A new medium is described for the selection and identification of Pseudomonas aeruginosa. It contains glycerol, mannitol, acetamide, cetrimide, a trace of peptone and phenol red. On this medium incubated at $42^{\circ} \mathrm{C}$, nearly all cultures of $P$ s. aeruginosa, but only very few other bacteria, form colonies or areas of growth surrounded by a red zone. The medium may be used either for the direct enumeration of Ps. aeruginosa or to establish the presence of this organism in liquid enrichment cultures.

We are grateful to the following for providing cultures of Ps. aeruginosa: Dr A. M. Bruining, St Joseph Hospital, Waalre; Professor L. Grün, University Clinics, Düsseldorf, Germany; Dr A. Kayser, University Clinics, Nijmegen; Dr J. Rechstein and Dr J. Coster, National Institute of Public Health, Utrecht; and to colleagues in our own Institutes, who also made cultures available for study. The valuable experimental assistance of Mrs D. Soedarmo and Miss C. van Zadelhoff is gratefully acknowledged. 


\section{REFERENCES}

AzUmA, Y., AND Witter, L. D. 1970. Pyocyanine degradation by apyocyanogenic strains of Pseudomonas aeruginosa. Canad. J. Microbiol., 16, 395.

Black, A. P., Keirn, M. A., Smith, J. J., JR, Dykes, G. M., JR, and Harlan, W. E. 1970. The disinfection of swimming pool water. Part II. A field study of the disinfection of public swimming pools. Amer. J. Publ. Hlth, 60, 740.

BRown, V. I., AND LowBURY, E. J. L. 1965. Use of an improved cetrimide agar medium and other culture methods for Pseudomonas aeruginosa. J. Clin. Path., 18, 752.

BühlmanN, X., Vischer, W. A., AND Bruhin, H. 1961. Die Identifizierung nicht Pyocyanin-bildender Stämme von Pseudomonas aeruginosa. Zentbl. Bakt. ParasitKde, Abt. I, Orig., 183, 368.

DRAKE, C. H. 1966. Evaluation of culture media for the isolation and enumeration of Pseudomonas aeruginosa. Hlth Lab. Sci., 3, 10.

Favero, M. S., Drake, C. H., and Randall, Georganne B. 1964. Use of staphylococci as indicators of swimming pool polution. Publ. Hlth Rep., Wash., 79, 61.

Goto, S., AND ENomoto, S. 1970. Nalidixic acid cetrimide agar. A new selective plating medium for the selective isolation of Pseudomonas aeruginosa. Jap. J. Microbiol., 14,65 .

HAYNeS, W. C. 1951. Pseudomonas aeruginosa-its characterization and identification. $J$. Gen. Microbiol., 5, 939.

Hedberg, Mary 1969. Acetamide agar medium selective for Pseudomonas aeruginosa. Appl. Microbiol., 17, 481.

Kelly, M., and Clark, Patricia H. 1962. An inducible amidase produced by a strain of Pseudomonas aeruginosa. J. Gen. Microbiol., 27, 305.

KielweIN, G. 1969. Ein Nährboden zur selektiven Züchtung von Pseudomonaden und Aeromonaden. Arch. Lebensmittelhyg., 20, 131.

Lowbury, E. J. L., AND Collins, A. G. 1955. The use of a new cetrimide product in a selective medium for Pseudomonas pyocyanea. J. Clin. Path., 8, 47.

Mossel, D. A. A., AND Martin, G. 1961. Milieu simplifié permettant l'étude des divers modes d'action des bactéries sur les hydrates de carbone. Annls Inst. Pasteur, Lille, $12,225$.

Pickett, M. J., AND Pedersen, Margaret M. 1970. Characterization of saccharolytic nonfermentative bacteria associated with man. Canad. J. Microbiol., 16, 351.

SeleEN, W. A., AND StaRK, C. N. 1943. Some characteristics of green-fluorescent pigmentproducing bacteria. J. Bact., 46, 491.

Selenka, F. 1960. Der quantitative Nachweis von Pseudomonas aeruginosa im Oberflächenwasser. Arch. Hyg. Bakt., 144, 627.

Stanier, R. Y., Palleroni, N. J., AND Doudoroff, M. 1966. The aerobic pseudomonads: a taxonomic study. J. Gen. Microbiol., 43, 159. 